\title{
Fear of COVID-19 as a precautionary measure to prevent the epidemic among the population of the Kurdistan Region/Iraq: based on a questionnaire survey
}

\author{
Azeez A. Barzinjy ${ }^{1,2}$ (D) $\cdot$ Kareem F. Aziz ${ }^{3} \cdot$ Bashdar M. Hussen $^{4} \cdot$ Saleem S. Qader $^{5} \cdot$ Samir M. Hamad $^{6,7} \cdot$ Arez S. Qader $^{8}$ • \\ Abdullah L. Jamal ${ }^{9}$
}

Received: 14 August 2020 / Accepted: 16 April 2021 / Published online: 3 May 2021

(C) The Author(s), under exclusive licence to Springer-Verlag GmbH Germany, part of Springer Nature 2021

\begin{abstract}
Background and objectives The World Health Organization (WHO) announced the appearance of a new coronavirus disease in Hubei province, China, to be a public health emergency of international concern. The objectives of this study can be highlighted through classifying the information sources for identifying protective practices, death probability, gender-death associations probability and education level.

Methodology This is a descriptive design study conducted among the Kurdistan Region/Iraq population via an online application between 1 March and 1 May 2020. Three hundred twenty people participated in this questionnaire study. The data were collected through an online form, relying upon a self-report questionnaire. The questionnaire had three main parts. The first part is related to the socio-demographic characteristics of the sample, including gender, age, family status, address status and education level. The second part involves the items related to precautionary measures using none, sometimes, and always. The last part contains items related to death probability owing to other causes and this includes five categories: extremely low, low, intermediate, high and extremely high. The validity and reliability of this questionnaire were revised by the panel of experts before the data collection.

Results The outcomes of the study revealed that the majority, ca. 73\%, of the Kurdistan Region/Iraq population depended on TV to obtain information about COVID-19. Also, this investigation showed that there is a substantial association between participants with infection prevention and control practices relevant to COVID-19. Moreover, according to this study, there is a significant relationship between the death probability and COVID-19. Concurrently, there is not any significant association between other causes, namely cancer, heart diseases, diabetes and road traffic accidents, and the death probability.

Conclusion This study showed that for the majority of the Kurdistan Region/Iraq population the most reliable source of information for any COVID-19 related updates is the TV broadcast. This study also indicated that there is strong association for the majority of individuals regarding their practices for prevention from COVID-19 and death probability with COVID-19. However, there is not any substantial association between the epidemic and the other deadly calamities and the death probability.
\end{abstract}

Keywords Fear · COVID-19 · Epidemic $\cdot$ Precautionary measure $\cdot$ Kurdistan region

Azeez A. Barzinjy

azeez.azeez@su.edu.krd

1 Department of Physics, Salahaddin University-Erbil, Erbil, Kurdistan-Region, Iraq

2 Physics Education Department, Tishk International University, Erbil, Kurdistan-Region, Iraq

3 College of Nursing, Hawler Medical University, Erbil, Kurdistan-Region, Iraq

4 Hawler Medical University/College of Pharmacy, Erbil, Kurdistan-Region, Iraq
5 Hawler Medical University/Kurdistan Board for medical speciality, Erbil, Kurdistan-Region, Iraq

6 Scientific Research Centre, Soran University, Soran, Kurdistan-Region 44008, Iraq

7 Computer Department, Cihan University-Erbil, Erbil, Kurdistan-Region, Iraq

8 PAKY Hospital, Erbil, Iraq

9 College of Business, University of Kurdistan-Hawler, Erbil, Kurdistan-Region, Iraq 


\section{Introduction}

In January 2020, the World Health Organization (WHO) declared the occurrence of a new coronavirus disease in Hubei province, China, to be a public health emergency of international concern. Moreover, this time of crisis has produced stress in the population (Wang et al. 2020). In fact, there are some common tips to help the reader to navigate this difficult period of time. First, one must understand their stress in such difficult circumstances and times. Also, one must comprehend that this is a global pandemic, blocking cities and even entire countries. It can be stated that some people live in areas and situations that have already been affected by the coronavirus, while others anticipate what may come and prepare to face these difficult circumstances (Lai et al. 2020). Nevertheless, there are numerous steps one might perform even in the face of this unprecedented disaster to control their anxiety and fears. Among these steps, one should stay informed; however, one must not randomly check the information. It is important to be updated, especially knowing what is happening in their network, so that one can follow the recommended safety precautions and do their part to slow the spread of the coronavirus (Cinelli et al. 2020). Also, social media may be a suitable tool, particularly in difficult circumstances, such as in recent time, where it is not easy to communicate with friends, family and acquaintances, but this helps one to feel connected through shared experiences with society, country and the entire world (Hageman 2020). When stress levels increase, then the nervous system will be out of balance. In this case, the relaxation techniques, including deep breathing, meditation and yoga, can bring one back into a state of balance or relaxation and reassurance. If one is staying with a group that does not face danger, staying at home, washing your hands frequently and remaining without contact with others, this can help to preserve lives. Accordingly, this also provides a strong protection against this virus and better aids the healthcare system (Krause et al. 2020). Numerous local social media companies can help one to connect with vulnerable people in their area. Therefore, this can be done by limiting their viewing, analysing news and attention to all kinds of information that makes one feel angry or anxious. On the other hand, one should depend on the statistics that are effective and reliable. This also means that one must retreat from public discourse and illogical and unscientific resources, especially this can be achieved by taking realistic steps to assemble your plans and defend yourself in a logical and proper way (Van Bavel et al. 2020). The unanticipated and almost steady flow of news reviews about malignant disease can cause everyone to feel a variety of anxieties. When it comes to getting the facts, which also means staying away from myths and misinformation, the facts should be gathered in record intervals and only from the WHO website and accredited health platforms. Accordingly, this will help to distinguish facts from rumours, and this of course will help reduce fears and face difficulties properly (Dong et al. 2020). Some problematic circumstances can be overcome by looking for opportunities to amplify the wonderful memories, hope and pleasant images of close humans who have suffered from COVID-19 (Ho et al. 2020). For instance, the minds of people who have recovered or supported a loved one and tend to share their experience (Duan and Zhu 2020). This can be done by protecting oneself and being supportive to others. Also, during times of stress, one should be aware of their personal needs and feelings. Engaging in healthful activities that bring a relaxation felling also is a positive parameter that helps one to control the situation (Singhal 2020). Generally, public health organizations and experts in all international locations are working on the outbreak to ensure the availability of quality care to those affected (Douglas et al. 2020).

The key objective of this investigation is to identify sources of information for the population of the Kurdistan Region/Iraq about COVID-19, define practices as a preventive case, determine the probability of death due to some diseases, and determine the relationship between gender and the probability of death. This study also highlights the effect of the individual's level of education on preventive practices. Moreover, this study is very important as it focuses on precautionary measures to protect individuals from the COVID-19 pandemic.

\section{Methodology}

This study is a descriptive and cross-sectional design, conducted among the Kurdistan Region/Iraq population via an online application between 1 March and 1 May 2020. It can be stated that The Kurdistan Region Government (KRG) is a semi-independent region in northern Iraq consisting of the four Kurdish-majority governorates of Erbil, Sulaymaniyah, Dohuk and Halabja and neighbouring Iran, Syria and Turkey (Fig. 1).

Erbil city is the capital of the KRG, and it is located in the north of Iraq, latitude $36^{\circ} 12^{\prime}$ and longitude $44^{\circ} 04^{\prime}$, among the area that is administrated by the KRG (Al-Kubaisi and Gardi 2012). According to UNESCO the Citadel in Erbil city, one of the world's oldest inhabited settlements, is aged between 3000 and 6000 years old (Akram et al. 2016). The sample size in this investigation was 320 participants. In addition, the participants, those who have the desire to participate, were selected from different districts in the Kurdistan Region/Iraq. In contrast, exclusion criteria included the group that refused to participate in the study.

\section{Tools and methods of data collection}

The utilized data in this study were collected via an online application form, through a self-report questionnaire. 


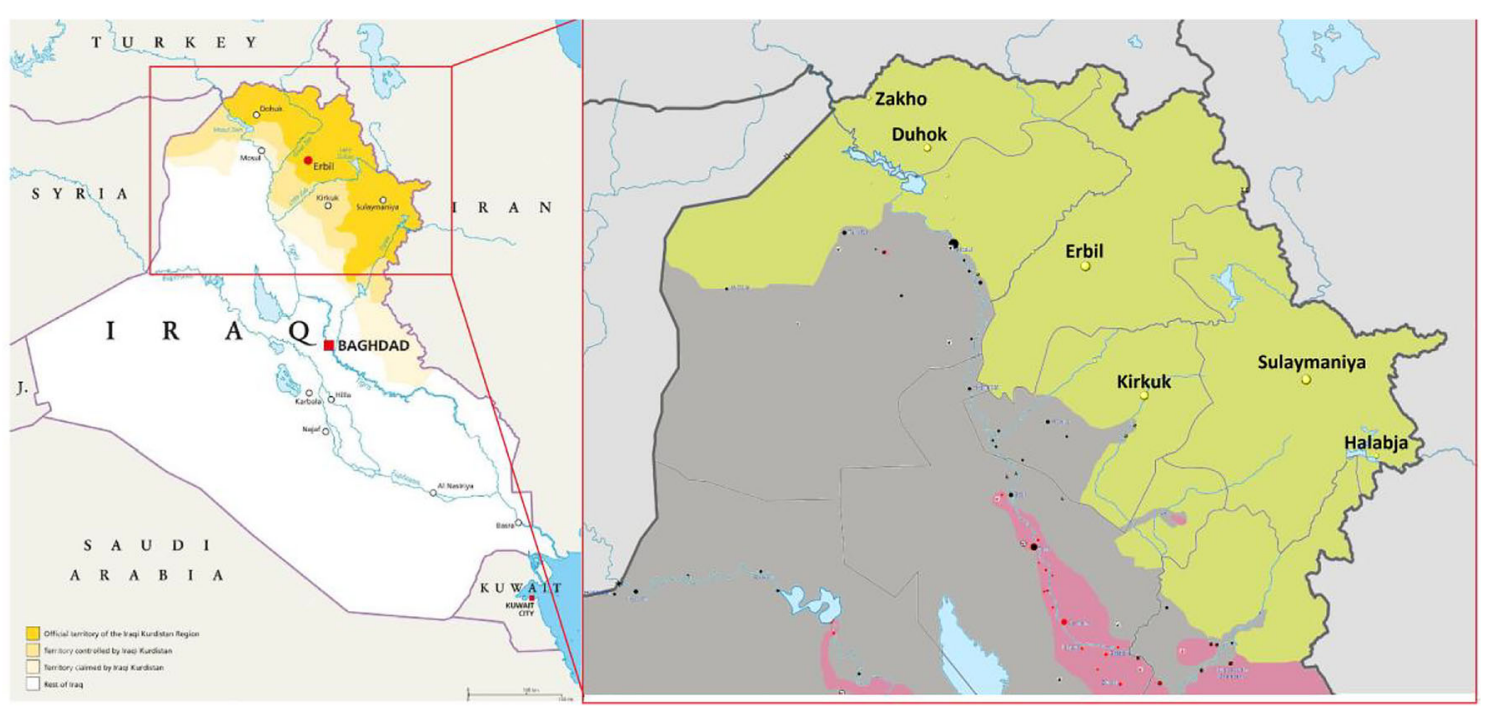

Fig. 1 The shaded area includes sampled areas from the Iraqi Kurdistan Region

Additionally, the questionnaire consists of three main parts. Part one was related to the socio-demographic characteristics of the sample, which include gender, age, family status, address status and education level. The second part consists of items related to precautionary measures using none, sometimes and always using a Likert scale. The last part includes issues related to death probability because of some causes and included five categories: extremely low, low, intermediate, high and extremely high. To highlight the importance of research and great credibility, the tool was presented to a committee of experts to ensure its suitability and validity before applying it and giving it to the participants for the purpose of data collection.

\section{Ethical considerations}

As an ethical consideration, the authors received permission from the Ethical and Scientific Committee of the Kurdistan Council of Medical Specialization. Accordingly, the authors promised to maintain the confidentiality of the information and to use this data for this study only.

\section{Data analysis}

The data were analysed using the Statistical Package for Social Science program version 26. This program includes descriptive statistical analysis, frequency and chi-square.

\section{Research problem}

One of the most important problems of this research is related to COVID-19 as a new health crisis, as one needs to find new ways of prevention and highlight the necessary steps to adapt to it.

\section{Results and discussion}

Figure 2 shows diverse sources of information about COVID19. It can be seen from Fig. 2 that among the 320 respondents from the Iraqi Kurdistan Region, only 4.4\% of them depend on radio, while $16.8 \%$ of the participants relying upon Twitter. However, $28.1 \%$ of the respondents use Instagram to get information about COVID-19. In addition, $64.4 \%$ of the respondents trust the health professionals. Moreover, approximately $71.2 \%$ use Facebook as a main source for collecting information about the COVID-19 pandemic. Finally, the largest portion of the participants, i.e. $72.8 \%$, depend on TV as a main source of information about this disease.

Table 1 shows socio-demographic characteristics of the sample study. It can be stated from Table 1 that among the 320 participants, 187 respondents were female, which made up approximately $58 \%$ of the total number of the participants, and 133 respondents were male, which made up approximately $42 \%$ of the entire number of the contributors. Table 1 covers a wide range of age groups, but the greatest number of the participants were between 19 and 24 years, which made up approximately $28 \%$. Regarding marital status, this study covers all of the common statuses, and approximately $53 \%$ of the participants were married. As stated previously, this study was conducted among the Iraqi Kurdistan Region population and the majority of the participants were from the capital city, i.e. Erbil, which formed approximately $77 \%$. This study also took the education level into consideration, and most of the participants, i.e. $58 \%$, were post graduates.

Table 2 characterizes protection measure practices among participants to prevent and reduce fear among them. It can be 
Fig. 2 The main sources of information about COVID-19

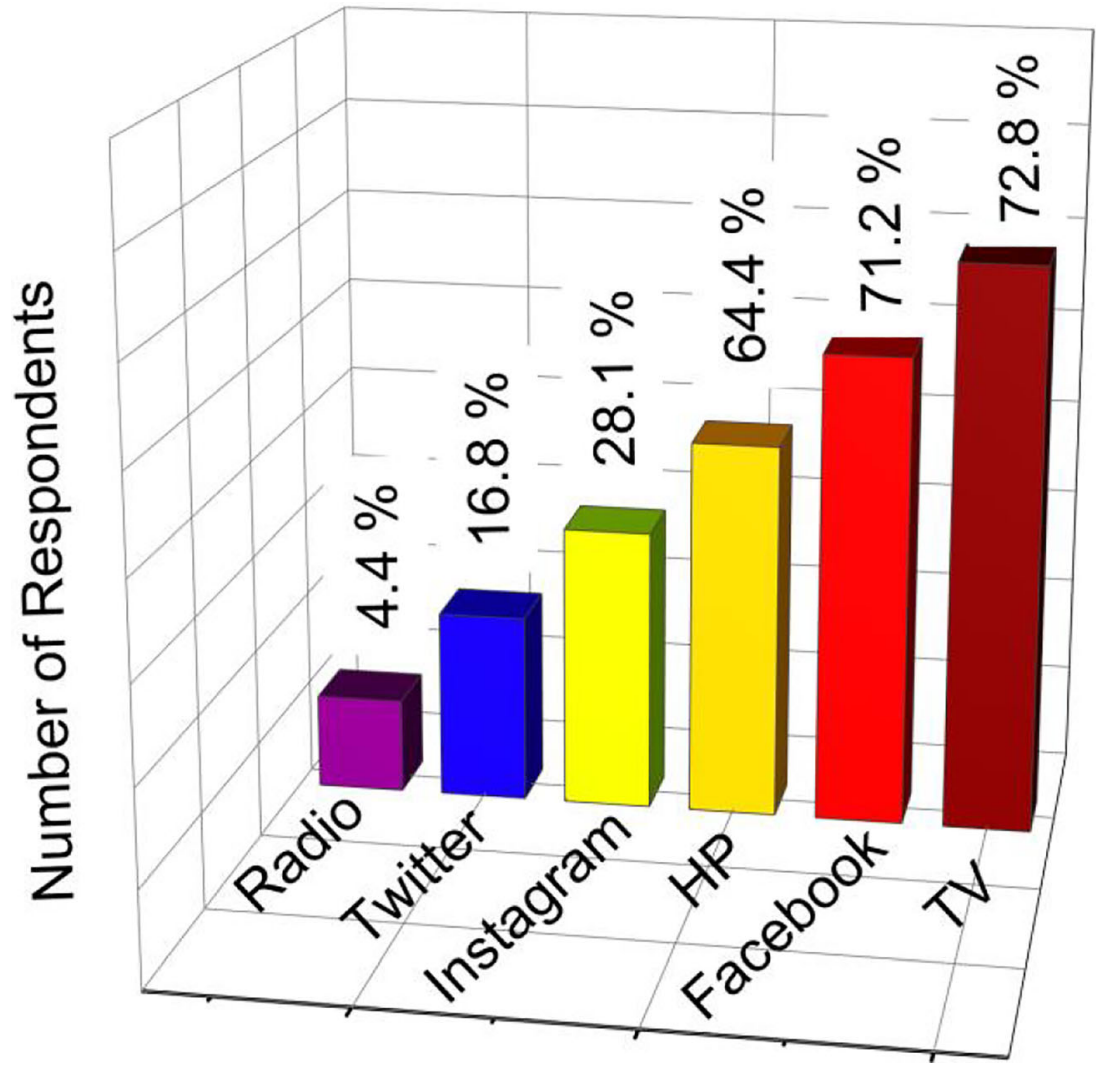

observed from Table 2 that the majority of the participants were postgraduates, which represents $58 \%$ of the respondents.

Table 1 Socio-demographic characteristics of the sample study

\begin{tabular}{|c|c|c|c|}
\hline \multicolumn{2}{|c|}{ Sociodemographic data } & \multirow{3}{*}{$\begin{array}{l}\text { Incidence } \\
133 \\
187\end{array}$} & \multirow{2}{*}{$\frac{\text { Percent }}{41.6 \%}$} \\
\hline Gender & Male & & \\
\hline & Female & & $58.4 \%$ \\
\hline \multicolumn{2}{|c|}{ Age (mean \pm std. deviation) } & \multicolumn{2}{|c|}{$32.76 \pm 12.11$} \\
\hline \multirow[t]{6}{*}{ Age group } & 18 years or younger & 24 & $7.5 \%$ \\
\hline & 19-24 years & 89 & $27.8 \%$ \\
\hline & 25-30 years & 25 & $7.8 \%$ \\
\hline & $31-36$ years & 74 & $23.1 \%$ \\
\hline & $37-42$ years & 44 & $13.8 \%$ \\
\hline & 43 years or older & 64 & $20.0 \%$ \\
\hline \multirow[t]{3}{*}{ Family status } & Single & 149 & $46.6 \%$ \\
\hline & Married & 169 & $52.8 \%$ \\
\hline & Divorced & 2 & $0.6 \%$ \\
\hline \multirow[t]{4}{*}{ Address } & Erbil & 247 & $77.2 \%$ \\
\hline & Sulaymaniyah & 41 & $12.8 \%$ \\
\hline & Duhok & 13 & $4.1 \%$ \\
\hline & Other cities (Halabja\& Kirkuk) & 19 & $5.9 \%$ \\
\hline \multirow[t]{4}{*}{ Education level } & High school & 10 & $3.1 \%$ \\
\hline & Undergraduate & 101 & $31.6 \%$ \\
\hline & Postgraduate & 186 & $58.1 \%$ \\
\hline & Others & 23 & $7.2 \%$ \\
\hline
\end{tabular}

This investigation showed that these participants always do the proper protection against COVID-19. For instance, 141 of them always wash hands frequently, 152 of them always avoid travel to affected places, 117 of them always stay at home and apply other necessary medical requirements. While, among the participants, the high school category adhered to fewer practices regarding protection from COVID19. They neither wash their hand frequently nor wear gloves and masks and they rarely stay at home. In general, the high school category followed fewer practices regarding protection from COVID-19 compared with the postgraduate category. On the other hand, the undergraduate participants follow more practices, sometimes and most of them avoid travel to affected places and stay at their home in order to avoid contact, while other participants adhered to fewer practices for the sake of prevention from COVID-19. It can be seen from Table 2 that there is a substantial link between the practices of prevention and level of education, as can be deduced from the $p$ value when it is less than $0.05 \%$. At the same time, there is not any significant connection between education level and their practices regarding wearing masks, gloves and avoiding large gathering, as can be deduced from the $p$ value when it is more than $0.05 \%$ (Zhu 2016).

Table 3 displays the probability of death by multiple common causes. It can be seen from Table 3 that cancer comes at the top, with 67 females, among the listed causes. While diabetes possesses the least order among males, with 27 . 
Table 2 Practices of protection measures against COVID-19 to decrease fear

\begin{tabular}{|c|c|c|c|c|c|}
\hline Protection against COVID-19 & Education level & None & Sometimes & Always & $\begin{array}{l}p \\
\text { value }\end{array}$ \\
\hline \multirow[t]{4}{*}{ Washing hands frequently } & $\begin{array}{l}\text { High-school } \\
(3.1 \%)\end{array}$ & $3(30 \%)$ & $3(30 \%)$ & $4(40 \%)$ & \multirow[t]{4}{*}{0.04} \\
\hline & $\begin{array}{l}\text { Undergraduate } \\
\quad(31.6 \%)\end{array}$ & $5(5 \%)$ & $18(17 \%)$ & $78(78 \%)$ & \\
\hline & $\begin{array}{c}\text { Postgraduate } \\
\quad(58.1 \%)\end{array}$ & $9(4.8 \%)$ & $36(19.4 \%)$ & $141(75.8 \%)$ & \\
\hline & Others $(7.2 \%)$ & $1(4.4 \%)$ & $2(8.6 \%)$ & $20(87 \%)$ & \\
\hline \multirow[t]{4}{*}{$\begin{array}{l}\text { Avoiding travel to affected } \\
\text { places }\end{array}$} & $\begin{array}{c}\text { High-school } \\
(3.1 \%)\end{array}$ & $4(40 \%)$ & $3(30 \%)$ & $3(30 \%)$ & \multirow[t]{4}{*}{0.01} \\
\hline & $\begin{array}{l}\text { Undergraduate } \\
\qquad(31.6 \%)\end{array}$ & $6(6 \%)$ & $11(10 \%)$ & $84(84 \%)$ & \\
\hline & $\begin{array}{c}\text { Postgraduate } \\
(58.1 \%)\end{array}$ & $12(6.4 \%)$ & $22(11.6 \%)$ & $152(82 \%)$ & \\
\hline & Others $(7.2 \%)$ & $1(4.3 \%)$ & $2(8.6 \%)$ & $20(87 \%)$ & \\
\hline \multirow[t]{4}{*}{ Stay at home } & $\begin{array}{c}\text { High-school } \\
(3.1 \%)\end{array}$ & $2(20 \%)$ & $6(60 \%)$ & $2(20 \%)$ & \multirow[t]{4}{*}{0.01} \\
\hline & $\begin{array}{l}\text { Undergraduate } \\
(31.6 \%)\end{array}$ & $8(8 \%)$ & $14(13 \%)$ & $79(79 \%)$ & \\
\hline & $\begin{array}{l}\text { Postgraduate } \\
\quad(58.1 \%)\end{array}$ & $16(8.6 \%)$ & $53(28.4 \%)$ & $117(63 \%)$ & \\
\hline & Others $(7.2 \%)$ & $1(4.3 \%)$ & $4(17.4 \%)$ & $18(78.3 \%)$ & \\
\hline \multirow[t]{4}{*}{$\begin{array}{l}\text { Avoiding people sneezing or } \\
\text { coughing }\end{array}$} & $\begin{array}{c}\text { High-school } \\
(3.1 \%)\end{array}$ & $3(30 \%)$ & $4(40 \%)$ & $3(30 \%)$ & \multirow[t]{4}{*}{0.04} \\
\hline & $\begin{array}{l}\text { Undergraduate } \\
\qquad(31.6 \%)\end{array}$ & $7(7 \%)$ & $31(30 \%)$ & $63(63 \%)$ & \\
\hline & $\begin{array}{c}\text { Postgraduate } \\
\quad(58.1 \%)\end{array}$ & $12(6.4 \%)$ & $43(23 \%)$ & $131(70.6 \%)$ & \\
\hline & Others $(7.2 \%)$ & $1(4.4 \%)$ & $2(8.6 \%)$ & $20(87 \%)$ & \\
\hline \multirow[t]{4}{*}{$\begin{array}{l}\text { Avoiding people suspected to be } \\
\text { sick }\end{array}$} & $\begin{array}{c}\text { High-school } \\
(3.1 \%)\end{array}$ & $3(30 \%)$ & $5(50 \%)$ & $2(20 \%)$ & \multirow[t]{4}{*}{0.01} \\
\hline & $\begin{array}{c}\text { Undergraduate } \\
\quad(31.6 \%)\end{array}$ & $9(9 \%)$ & $15(14.8)$ & $77(76.2 \%)$ & \\
\hline & $\begin{array}{c}\text { Postgraduate } \\
(58.1 \%)\end{array}$ & $12(6.4 \%)$ & $37(20 \%)$ & $137(73.6 \%)$ & \\
\hline & Others $(7.2 \%)$ & $1(4.3 \%)$ & $4(17.5 \%)$ & $18(78.2 \%)$ & \\
\hline \multirow[t]{4}{*}{$\begin{array}{l}\text { Avoiding large } \\
\text { gathering/meetings }\end{array}$} & $\begin{array}{c}\text { High-school } \\
(3.1 \%)\end{array}$ & $1(10 \%)$ & $6(60 \%)$ & $3(30 \%)$ & \multirow[t]{4}{*}{0.08} \\
\hline & $\begin{array}{l}\text { Undergraduate } \\
\quad(31.6 \%)\end{array}$ & $7(7 \%)$ & $20(19 \%)$ & $74(74 \%)$ & \\
\hline & $\begin{array}{c}\text { Postgraduate } \\
(58.1 \%)\end{array}$ & $10(5.3 \%)$ & $34(18.3 \%)$ & $142(76.4 \%)$ & \\
\hline & Others $(7.2 \%)$ & $0(0 \%)$ & $3(13 \%)$ & $20(87 \%)$ & \\
\hline \multirow[t]{4}{*}{ Wearing gloves and masks } & $\begin{array}{c}\text { High-school } \\
(3.1 \%)\end{array}$ & $6(60 \%)$ & $4(40 \%)$ & $0(0 \%)$ & \multirow[t]{4}{*}{0.07} \\
\hline & $\begin{array}{l}\text { Undergraduate } \\
\qquad(31.6 \%)\end{array}$ & $19(19 \%)$ & $47(47 \%)$ & $35(34 \%)$ & \\
\hline & $\begin{array}{c}\text { Postgraduate } \\
\quad(58.1 \%)\end{array}$ & $29(15.6 \%)$ & $86(46.2 \%)$ & $71(38.2 \%)$ & \\
\hline & Others $(7.2 \%)$ & $3(13 \%)$ & $10(43.5 \%)$ & $10(43.5 \%)$ & \\
\hline
\end{tabular}

However, there is a significant association between the probability of death by COVID-19, as can be deduced from the $p$ value which is less than $0.05 \%$. On the other hand, there is no significant relationship between the death probability and cancer, heart disease, diabetic, smoking and road traffic accidents, since the $p$ value is higher than $0.05 \%$.
The findings of the study revealed that the majority of the population, approximately $73 \%$, in the KRG depend on TV for obtaining information about COVID-19, while a minority, roughly $4 \%$, of the participants depend on radio for information about this pandemic. Zhong et al. found similar outcomes among Chinese residents during the rapid rise period of the 
Table 3 Probability of death by multiple causes and fear about that

\begin{tabular}{|c|c|c|c|c|c|c|c|}
\hline Causes & Gender & $\begin{array}{l}\text { Extremely } \\
\text { low }\end{array}$ & Low & Intermediate & High & $\begin{array}{l}\text { Extremely } \\
\text { high }\end{array}$ & $\begin{array}{l}p \\
\text { value }\end{array}$ \\
\hline \multirow[t]{2}{*}{ COVID-19 } & $\begin{array}{r}\text { Female } \\
(187)\end{array}$ & $19(10 \%)$ & $68(36 \%)$ & $78(42 \%)$ & $18(9.6 \%)$ & $4(2.4 \%)$ & \multirow[t]{2}{*}{0.001} \\
\hline & $\begin{array}{l}\text { Male } \\
\text { (133) }\end{array}$ & $39(29 \%)$ & $54(41 \%)$ & $32(24 \%)$ & $8(6 \%)$ & $0(0 \%)$ & \\
\hline \multirow[t]{2}{*}{ Cancer } & $\begin{array}{r}\text { Female } \\
(187)\end{array}$ & $8(4.2 \%)$ & $18(9.6 \%)$ & $78(42 \%)$ & $67(36 \%)$ & $16(8.2 \%)$ & \multirow[t]{2}{*}{0.9} \\
\hline & $\begin{array}{l}\text { Male } \\
\text { (133) }\end{array}$ & $6(4.5 \%)$ & $26(19.5 \%)$ & $44(33 \%)$ & $45(34 \%)$ & $12(9 \%)$ & \\
\hline \multirow[t]{2}{*}{ Heart disease } & $\begin{array}{r}\text { Female } \\
(187)\end{array}$ & $9(5 \%)$ & $18(10 \%)$ & $76(40 \%)$ & $63(34 \%)$ & $21(11 \%)$ & \multirow[t]{2}{*}{0.6} \\
\hline & $\begin{array}{l}\text { Male } \\
\text { (133) }\end{array}$ & $5(3.7 \%)$ & $17(13 \%)$ & $48(36 \%)$ & $53(40 \%)$ & $10(7.3 \%)$ & \\
\hline \multirow[t]{2}{*}{ Diabetes } & $\begin{array}{r}\text { Female } \\
\text { (187) }\end{array}$ & $10(5.3 \%)$ & $45(24 \%)$ & $83(44.4 \%)$ & $41(22 \%)$ & $8(4.3 \%)$ & \multirow[t]{2}{*}{0.1} \\
\hline & $\begin{array}{l}\text { Male } \\
\text { (133) }\end{array}$ & $12(9 \%)$ & $33(25 \%)$ & $60(45.3 \%)$ & $27(20 \%)$ & $1(0.7 \%)$ & \\
\hline \multirow[t]{2}{*}{$\begin{array}{r}\text { Road traffic } \\
\text { accidents }\end{array}$} & $\begin{array}{r}\text { Female } \\
(187)\end{array}$ & $7(3.7 \%)$ & $18(9.3 \%)$ & $67(36 \%)$ & $58(31 \%)$ & $(20 \%)$ & \multirow[t]{2}{*}{0.3} \\
\hline & $\begin{array}{l}\text { Male } \\
\text { (133) }\end{array}$ & $6(4.5 \%)$ & $20(15 \%)$ & $50(37.5 \%)$ & $36(27 \%)$ & $21(16 \%)$ & \\
\hline \multirow[t]{2}{*}{ Smoking } & $\begin{array}{r}\text { Female } \\
(187)\end{array}$ & $24(13 \%)$ & $15(8 \%)$ & $75(40 \%)$ & $59(31.5 \%)$ & $14(7.5 \%)$ & \multirow[t]{2}{*}{0.1} \\
\hline & $\begin{array}{l}\text { Male } \\
\text { (133) }\end{array}$ & $15(11.3 \%)$ & $24(18 \%)$ & $43(32.3 \%)$ & $40(30 \%)$ & $11(8.4 \%)$ & \\
\hline
\end{tabular}

COVID-19 outbreak (Zhong et al. 2020). The language being used in the media to describe the outbreak is undoubtedly contributing to the mass hysteria about the disease. Analogous to our results, other investigations stated that contributors typically attained their information about COVID-19 through the internet and watching TV (Tork and Mersal 2018). Nemati et al., in a similar study on Iranian Nurses, indicated that they strengthen their knowledge about infectious diseases through the internet and watching TV (Nemati et al. 2020).

Other findings of the study indicated that there is a substantial connection between the level of education and the participants practices to prevent COVID-19 and decrease their fear (Blbas 2020). This is already expected, as shown in Table 2, because the $p$ value is less than $0.05 \%$. Zhong et al. in their study stated that the majority of the respondents agreed that COVID-19 will eventually be successfully controlled (90.8\%) (Zhong et al. 2020). This is more likely due to the education level of the participants. It can be understood that health education programs are significant for improving COVID-19 facts and supportive for KRG residents to hold positive attitudes and maintain suitable preventative measures.

Refering to Table 2, one can see that, except in items wearing masks, gloves and avoiding crowded places, there is no significant relationship with education level, since the $p$ value is more than $0.05 \%$. These findings agree well with the WHO reports regarding the population behaviours to cope with COVID-19 in order to reduce fear and anxiety and improve their awareness for prevention. The report stated that people are psychologically affected by and dealing with the COVID19 emergency (Qiu et al. 2020). The findings of the study indicated that there is a significant association between gender and COVID-19 as the probability of death (Table 3) because most of the population are afraid of death and onset of the virus to their respiratory systems. These findings agree well with Richardson et al.'s investigation (Richardson et al. 2020).

At the same time, there is not any significant link between other causes such as cancer, heart diseases, diabetes and road traffic accidents since these causes are not as frightening as COVID-19 (Madabhavi et al. 2020).

These findings also agree with WHO reports about the fear from COVID-19 which has come to dominate news headlines of all forms. These news and reports, in turn, increase the anxiety and fear of the recipient, thus making them obsessive and afraid of injury and death. Currently, the level of fear of COVID-19 among the KRG population is not known precisely, although the levels of fear are high among our neighbouring countries, such as Iran, where there have been many deaths, as stated by a current study investigating fear of COVID-19 (Ahorsu et al. 2020).

\section{Conclusion}

This study found that the levels of consciousness and anxiety about COVID-19 were high in the KRG. The majority of the KRG population, nearly $73 \%$, depend on TV to get information about COVID-19. Approximately $58 \%$ of the participants 
were postgraduates, and thus there was a significant association between their practices for prevention and COVID-19. This study indicated that there is a significant relationship between the death probability and COVID-19. At the same time, there is not any significant relationship between other causes such as cancer, heart diseases, diabetes, road traffic accidents and the death probability.

This study aimed to assess COVID-19 in KRG because there is a crucial requirement to comprehend the public's consciousness of COVID-19 at this difficult time period. Additionally, this study aimed to reduce the risk of developing distress, improve welfare, as well as promote preventive behaviours. Furthermore, through this investigation the authors can offer evidence-based strategies for governments and policymakers in order to improve the public knowledge and clinical intervention systems. The authors believe that epidemic-related problems such as segregation and quarantine can cause psychological status such as fear and nervousness.

The fear and nervousness towards COVID-19 can be decreased by avoiding unreliable news and information sources, such as social media and public talks. Finally, as a result of the limited representative sample, the authors advise exercising caution when generalizing these conclusions to groups with low socioeconomic status.

Acknowledgements The authors thank all of the respondents in this study for their voluntary participation and providing the essential information. Our sincere thanks goes to Dr. David M.W. Waswa at Tishk International University for his diligent proofreading of this manuscript.

Authors' contributions The authors contributions in this manuscript are as the following:

Azeez A. Barzinjy is the corresponding author and he was responsible for writing, presenting and publication.

Kareem F. Aziz was responsible for designing and preparing the utilized questionnaire, analysing the data and writing.

Bashdar M. Hussen was responsible for statistical measurement and writing.

Saleem S. Qader was in contact with the Ethical and Scientific Committee of the Kurdistan Council of Medical Specialization to gain permission and participated in interpreting the outcomes.

Samir M. Hamad was responsible for the final design, proofreading and data analysing.

Arez S. Qader was responsible for online requirement and dealing with the received data and presentation in the tables and graphs.

Abdullah L. Jamal was responsible for the statistical parts and using professional program tools for analysing the data.

Funding The authors declare that they did not receive any funding for this research.

\section{Availability of data and material Not applicable.}

\section{Declarations}

Conflicts of interest The authors declare that they have no conflict of interest.
Ethics approval As an ethical consideration, the authors received permission from the Ethical and Scientific Committee of the Kurdistan Council of Medical Specialization.

Consent to participate The data of this study were collected via an online application form, through a self-report questionnaire and 320 participants participated voluntarily.

\section{References}

Ahorsu DK, Lin C-Y, Imani V, Saffari M, Griffiths MD, Pakpour AH (2020) The Fear of COVID-19 Scale: development and initial validation. Int J Ment Health Addict. https://doi.org/10.1007/s11469-020-00270-8

Akram OK, Ismail S, Franco DJ (2016) The significant of urban form of Erbil city, Iraq. Int J Eng Technol Manag Appl Sci 4:96-101

Al-Kubaisi QY, Gardi LM (2012) Dust storm in Erbil city as a result of climatic change in Kurdistan Region Iraq. Iraqi J Sci 53:40-44

Blbas HTA, Aziz KF, Nejad SH, Barzinjy AA (2020) Phenomenon of depression and anxiety related to precautions for prevention among population during the outbreak of COVID-19 in Kurdistan Region of Iraq: based on questionnaire survey. J Public Health:1-5

Cinelli $\mathrm{M}$ et al (2020) The COVID-19 social media infodemic. arXiv preprint. arXiv:2003.05004

Dong E, Du H, Gardner L (2020) An interactive web-based dashboard to track COVID-19 in real time. Lancet Infect Dis 20:533-534

Douglas M, Katikireddi SV, Taulbut M, McKee M, McCartney G (2020) Mitigating the wider health effects of covid-19 pandemic response. BMJ 369. https://doi.org/10.1136/bmj.m1557

Duan L, Zhu G (2020) Psychological interventions for people affected by the COVID-19 epidemic. Lancet Psychiat 7:300-302

Hageman JR (2020) The coronavirus disease 2019 (COVID-19). Pediatr Ann 49:e99-e100

Ho CS, Chee CY, Ho RC (2020) Mental health strategies to combat the psychological impact of COVID-19 beyond paranoia and panic. Ann Acad Med Singapore 49:1-3

Krause NM, Freiling I, Beets B, Brossard D (2020) Fact-checking as risk communication: the multi-layered risk of misinformation in times of COVID-19. J Risk Res. https://doi.org/10.1080/13669877.2020. 1756385

Lai C-C, Shih T-P, Ko W-C, Tang H-J, Hsueh P-R (2020) Severe acute respiratory syndrome coronavirus 2 (SARS-CoV-2) and coronavirus disease-2019 (COVID-19): the epidemic and the challenges. Int J Antimicrob Agents 55:105924. https://doi.org/10.1016/j. ijantimicag.2020.105924

Madabhavi I, Sarkar M, Kadakol N (2020) COVID-19: a review. Monaldi Arch Chest Dis 90(2). https://doi.org/10.4081/monaldi.2020.1298

Nemati M, Ebrahimi B, Nemati F (2020) Assessment of Iranian nurses' knowledge and anxiety toward COVID-19 during the current outbreak in Iran. Arch Clin Infect Dis 15:e102848. https://doi.org/10. 5812/archcid. 102848

Qiu J, Shen B, Zhao M, Wang Z, Xie B, Xu Y (2020) A nationwide survey of psychological distress among Chinese people in the COVID-19 epidemic: implications and policy recommendations. Gen Psychiat 33: e100213. https://doi.org/10.1136/gpsych-2020-100213

Richardson S et al (2020) Presenting characteristics, comorbidities, and outcomes among 5700 patients hospitalized with COVID-19 in the New York City area. JAMA 323:2052-2059. https://doi.org/10. 1001/jama.2020.6775

Singhal T (2020) A review of coronavirus disease-2019 (COVID-19). Indian J Pediat 87:281-286. https://doi.org/10.1007/s12098-02003263-6

Tork HM, Mersal FA (2018) Middle East respiratory syndrome-Corona virus: knowledge and attitude of Qassim University students, KSA 
Van Bavel JJ et al (2020) Using social and behavioural science to support COVID-19 pandemic response. Nat Hum Behav 4:460-471. https:// doi.org/10.1038/s41562-020-0884-z

Wang C, Horby PW, Hayden FG, Gao GF (2020) A novel coronavirus outbreak of global health concern. Lancet 395:470-473

Zhong B-L, Luo W, Li H-M, Zhang Q-Q, Liu X-G, Li W-T, Li Y (2020) Knowledge, attitudes, and practices towards COVID-19 among Chinese residents during the rapid rise period of the COVID-19 outbreak: a quick online cross-sectional survey. Int J Biol Sci 16: 1745

Zhu W (2016) $p<0.05,<0.01,<0.001,<0.0001,<0.00001,<0.000001$, or $<0.0000001 \ldots$ J Sport Health Sci 5:77. https://doi.org/10.1016/j. jshs.2016.01.019

Publisher's note Springer Nature remains neutral with regard to jurisdictional claims in published maps and institutional affiliations. 